\title{
Os tormentos da memória trauma e narrativa nos escritos de Primo Levi*
}

\author{
The torments of memory \\ trauma and narrative in Primo Levi's writings
}

\author{
GERALDO ANTONIO SOARES \\ Professor do Departamento de História \\ Universidade Federal do Espírito Santo (UFES) \\ Av. Fernando Ferrari, 514, Campus Universitário de Goiabeiras \\ CEP 29075-910 - Vitória - ES \\ geraldosoares12@gmail.com
}

RESUMO $O$ escritor e químico italiano Primo Levi passou um longo ano de sua vida no campo de concentração de entre 1944 e 1945. Uma vez liberto do campo, ele começa a escrever suas memórias deste período e publica seu primeiro livro $E$ isto um homem? em 1947, seguido de outras obras, inclusive de ficção. Mas ele sempre se questionou se valia a pena resgatar e registrar o que viveu no campo. Pensava que havia uma espécie de dever de memória que poderia resultar num legado para as gerações futuras, evitando que barbáries como essa voltassem a ocorrer. Mas sentia também a necessidade do esquecimento, tamanho foi o trauma vivido e a vergonha daquilo que os seres humanos chegaram a fazer com outros seres humanos. Examinando o conjunto de sua obra, trataremos aqui desta complexa relação entre memória, esquecimento e narrativa e de sua importância para a história.

Palavras-chave memória, narrativa, Primo Levi

* Artigo recebido em: 26/06/2011. Aprovado em: 20/12/2011. 
ABSTRACT The Italian writer and chemist Primo Levi spent a long year of his life at the Auschwitz concentration camp between 1944 and 1945. Once freed from the camp, he starts to write his memoirs of this period and publishes his first book "If this is a man" in 1947, followed by others, including fiction. However, he always questioned whether it was worthwhile to recover and leave records of what he witnessed in the camp. If, on the one hand, he thought of his writing as some sort of duty of memory that could result in a legacy for future generations thus preventing barbarities of this kind to repeat, on the other, he felt the need to forget, given the trauma experienced and the shame at what human beings were capable of doing to other human beings. By examining his work as a whole, we will take a closer look at the complex relation between memory, forgetting, narrative and their importance to history.

Keywords memory, narrative, Primo Levi

No campo de concentração de Monowitz, pertencente ao complexo de campos de concentração de Auschwitz, na Alta Silésia, a aproximadamente 60 $\mathrm{km}$ a oeste da cidade polonesa de Cracóvia, no qual foi um dos prisioneiros entre fevereiro de 1944 e janeiro de 1945, o químico e escritor italiano Primo Levi (1919-1987) fez amizade com um ex-sargento do exército austro-húngaro, Cruz de Ferro da Primeira Guerra Mundial, de nome Steinlauf. Este seu amigo o exortava sempre a se manter limpo, tomando banho, mesmo com água suja, sem ter sabão e toalha e tendo que se enxugar com o próprio casaco. Não para atender a disciplina imposta pelos alemães e sim para dar um sentido à vida que levavam ali. Justamente pelo fato de ter sido o campo de concentração concebido como uma grande engrenagem para transformar os prisioneiros em animais, eles não deviam permitir isto. Não deviam se entregar e dar o seu consentimento. Até num lugar como aquele era possível sobreviver para relatar a verdade, para darem seus testemunhos, de acordo com Steinlauf. Era então necessário resistir. Embora Primo Levi reconheça que esta foi uma lição essencial para sua sobrevivência, a dúvida sempre o assaltava. Será mesmo necessário elaborar um sistema e observá-lo? E se tudo aquilo não possuísse sentido algum?

Notamos que esta era uma angústia que sempre o acometia. Se por um lado é necessário testemunhar, por outro, fica sempre a dúvida se o que se diz corresponde inteiramente ao ocorrido, tamanho é o trauma. Esta angústia se revela como nunca no sentimento de estar sendo injusto com os que morreram porque só eles é que estariam autorizados a testemunhar a imensidão do sofrimento. Os que sobreviveram não teriam vivido plenamente a realidade do 
campo, caso em que, como a quase totalidade dos judeus que por ali passaram, teriam também sucumbido. Mas justamente ao falar pelos companheiros mortos, é que se revela a função primordial do testemunho, já que aqui, mais do que nunca, aparece um dos sentidos do discurso da história, qual seja, o de que "é de qualquer modo a função do discurso como lugar da palavra oferecer aos mortos uma terra e um túmulo". ${ }^{1}$

Se, a partir de suas dúvidas sobre se devia ou não narrar tudo que passou no campo, Primo Levi tivesse optado pela busca do esquecimento e da refutação da memória, ele provavelmente encontraria uma razão a mais para considerar os alemães como vencedores em seu projeto de extermínio na medida em que eles também visavam o desaparecimento completo de suas vítimas. É o que nos diz Hannah Arendt: "Nos países totalitários, todos os locais de detenção administrados pela polícia constituem verdadeiros poços de esquecimento onde as pessoas caem por acidente, sem deixar atrás de si os vestígios tão naturais de uma existência como um cadáver ou uma sepultura". ${ }^{2}$

O sobrevivente dos campos passa a viver com um sentimento de culpa difuso e insuperável. Convivem também com uma vergonha - injustificável para nós, mas nem por isto menos real para eles - que pode ser definida a partir dos seguintes componentes, segundo Tzvetan Todorov: primeiro, a vergonha da lembrança ou, na medida em que fica privado de sua vontade e que é reduzido à impotência, de realizar uma série de atos visando a sobrevivência, que julga abjetos e indignos de um ser humano; há também a vergonha por sobreviver ou de ter ocupado o lugar de outro melhor do que ele, já que aquele não teria usado os mesmos expedientes que ele condena para sobreviver; e, enfim, a mais abstrata, a vergonha de ser humano, o sentimento de que "pertencemos a uma espécie cujos representantes realizaram atos atrozes e sabemos que não podemos nos proteger contra as implicações deste fato declarando que estas pessoas são loucas e monstruosas; não, somos feitos do mesmo barro". ${ }^{3}$

Em seu livro sobre o julgamento de Adolf Eichmann, que se propõe exatamente a produzir um relato sobre a banalidade do mal, Hannah Arendt chama atenção para o fato de que o réu, que foi o responsável direto pela deportação dos judeus de territórios ocupados da Áustria, Polônia e Hungria para os campos de concentração, não era nenhum monstro. Era o que poderíamos considerar como um homem comum, não muito diferente da maioria das pessoas que viviam na Alemanha na época do Terceiro Reich. Mas ali, na Alemanha

RICOEUR, Paul. La mémoire, l'histoire, l'oubli. Paris: Seuil, 2000, p.480.

2 ARENDT, Hannah. Origens do totalitarismo. Tradução de Roberto Raposo. São Paulo: Companhia das Letras, 1989, p.485.

3 TODOROV, Tzvetan. Em face do extremo. Tradução de Egon O. Rangel e Enid A. Dobránszky. Campinas, SP: Papirus, 1995, p.288-290. 
nazista, a vida não seguia o seu curso ordinário e as pessoas não eram mais tão comuns:

E assim como a lei de países civilizados pressupõe que a voz da consciência de todo mundo dita 'Não matarás', mesmo que o desejo e os pendores do homem natural sejam às vezes assassinos, assim a lei da terra de Hitler ditava à consciência de todos: 'Matarás', embora os organizadores do massacre soubessem muito bem que o assassinato era contra os desejos e os pendores normais da maioria das pessoas. No Terceiro Reich, o Mal perdera a qualidade pela qual a maior parte das pessoas o reconhecem - a qualidade da tentação. ${ }^{4}$

Mas nem todos somos capazes de matar e torturar. Como assinala Tzvetan Todorov, o fato de sermos todos feitos do mesmo barro não significa que devemos ignorar o abismo que separa o possível do real:

Sem dúvida somos todos egoístas, mas nem todos nos tornamos racistas e, entre os racistas, somente os nazistas, na Europa, chegaram ao extremo que é o extermínio racial. Os homens são todos potencialmente capazes do mesmo mal, mas não o são efetivamente, pois não tiveram as mesmas experiências: sua capacidade de amor, de compaixão, de julgamento moral ou foi cultivada e se desenvolveu ou, ao contrário, foi sufocada e desapareceu. ${ }^{5}$

Memória, morte e testemunho se entrelaçam na experiência do sobrevivente dos campos. Um testemunho de uma realidade passada que, por ser absurda na sua desumanidade, renasce com uma enorme dificuldade:

Aquele que testemunhou sobreviveu - de modo incompreensível - à morte: ele como que a penetrou. Se o indizível está na base da língua, o sobrevivente é aquele que reencena a criação da língua. Nele a morte - o indizível por excelência, que a toda hora tentamos dizer - recebe novamente o cetro e o império sobre a linguagem. 0 simbólico e o real são recriados na sua relação de mútua fertilização e exclusão. ${ }^{6}$

Sobre o valor do testemunho, sobre sua incompletude e sobre a dificuldade em narrar toda a realidade, lembra Shoshana Felman que a partir de Freud, em $A$ interpretação dos sonhos, a psicanálise repensa profundamente e renova radicalmente o próprio conceito de testemunho, e isto se dá

4 ARENDT, Hannah. Eichmann em Jerusalém: um relato sobre a banalidade do mal. Tradução de José Rubens Siqueira. São Paulo: Companhia das Letras, 1999, p.167.

5 TODOROV, Tzvetan. Memória do mal, tentação do bem: indagações sobre o século XX. Tradução de Joana Angélica D. Melo. São Paulo: Arx, 2002, p.147.

6 SELIGMANN-SILVA, Márcio. Apresentação da questão: a literatura do trauma. In: SELIGMANN-SILVA, Márcio. (org.) História, memória, literatura: o testemunho na era das catástrofes. Campinas: Editora da Unicamp, 2003, p.52. 
ao sugerir e ao reconhecer, pela primeira vez na história da cultura, que não é necessário possuir ou ser dono da verdade para testemunhar sobre ela de forma eficiente; que o discurso, enquanto tal, é testemunhal sem o saber e que aquele que fala, constantemente testemunha uma verdade que, apesar disso, continua a lhe escapar. Uma verdade que é, essencialmente, inacessível para o próprio orador. ${ }^{7}$

No campo de concentração, a personalidade corria maior risco que a própria vida. O campo funcionava como um laboratório para a morte. Além do trabalho forçado, interessava aos que o montaram experiências destrutivas da vida. A idéia de eugenia, associada à de produção de uma raça superior ariana, se ligava também a um projeto de destruição daqueles considerados inferiores. Mas não se tratava da mera destruição física, caso em que os prisioneiros poderiam ter sido executados sem a montagem de toda a estrutura dos campos. Estudava-se ali como eliminar pessoas, como destruí-las de modo integral. Saber disso, ter vivido na própria pele a constatação de onde chegamos, era assustador a ponto de os sobreviventes questionarem se valia a pena levar para fora do campo o que acontecia com eles ou se era melhor deixar morrer com eles, ali mesmo, toda aquela miséria. Primo Levi nos relata esta sua angústia:

Viajamos até aqui nos vagões chumbados; vimos partir rumo ao nada nossas mulheres e nossas crianças; nós, feito escravos, marchamos cem vezes, ida e volta, para a nossa fadiga, apagados na alma antes que pela morte anônima. Não voltaremos. Ninguém deve sair daqui; poderia levar ao mundo, junto com a marca gravada na carne, a má nova daquilo que, em Auschwitz, o homem chegou a fazer ao homem. ${ }^{8}$

Este apagamento da vida, da alma e esta morte anônima era o que se pretendia nos campos e era a tudo isto que se procurava resistir com enormes dificuldades:

Os campos de concentração, tornando anônima a própria morte e tornando impossível saber se um prisioneiro está vivo ou morto, roubaram da morte o significado de uma vida realizada. Em certo sentido, roubaram a própria morte do indivíduo, provando que, doravante, nada - nem a morte - lhe pertencia e que ele não pertencia a ninguém. A morte apenas selava o fato de que ele jamais havia existido. ${ }^{9}$

7 FELMAN, Shoshama. Educação e crise, ou as vicissitudes do ensino. In: NESTROVSKI, Arthur e SELIGMANNSILVA, Márcio. (org.) Catástrofe e representação. São Paulo: Escuta, 2000, p.27.

8 LEVI, Primo. É isto um homem? Tradução de Luigi Del Re. Rio de Janeiro: Rocco, 1988, p.55.

9 ARENDT, Hannah. Origens do totalitarismo, p.503. 
O esquecimento não seria então melhor que a lembrança? Uma pergunta que não tem uma resposta simples, como bem lembra Tzvetan Todorov. Não cabe a nós cobrar dos sobreviventes qualquer espécie de dever de memória ou de testemunho. Eles têm tanto o direito à lembrança como ao esquecimento. $\mathrm{Na}$ democracia, "a recuperação do passado é um direito legítimo, mas não se pode fazer disso um dever. Haveria uma crueldade infinita em lembrar a alguém os acontecimentos mais dolorosos de seu passado; o direito ao esquecimento existe também". ${ }^{10}$

A memória, que para Paul Ricoeur é a matriz da história e não meramente um de seus objetos, não deve se tornar uma obrigação. 0 dever de memória se inscreve nas questões relativas ao uso e abuso da memória: dizer você se lembrará, é também dizer você não se esquecerá. Poderíamos dizer mesmo que "o dever de memória constitui ao mesmo tempo o cúmulo do bom uso e do abuso da memória". Prossegue, dando ênfase à estranheza no próprio paradoxo gramatical que existe nesta imposição de se lembrar: como é possível dizer você se lembrará, remetendo então ao futuro esta memória que se coloca como guardiã do passado? Mais grave ainda: como pode ser possível dizer você deve se lembrar, devendo então você remeter a memória ao modo imperativo, enquanto que é um traço marcante da lembrança o de poder surgir na maneira de uma evocação espontânea? ${ }^{11}$

Para os sobreviventes, relatar o que ocorria no campo de concentração nunca foi fácil, a começar pela dificuldade em fornecer uma ideia da dimensão da perda. Não eram apenas os parentes, os amigos e os entes queridos que se perdia. Perdia-se também a casa, a roupa, os utensílios do dia a dia - nos campos uma faca e uma colher eram artigos valorizados e sua perda trazia sérias complicações. Perdendo tudo isto, perde-se também a dignidade e a capacidade de discernimento, pois "quem perde tudo, muitas vezes perde também a si mesmo". ${ }^{12}$ Um homem ou uma mulher assim destituído se transforma em um ser vazio, reduzido a puro sofrimento e carência e em relação ao qual a decisão de sua eliminação se transforma numa questão de conveniência. A expressão "campo de extermínio" possui esse sentido de um espaço-tempo em que pessoas, no caso, os judeus, estavam sendo preparadas para morrer.

No momento em que trata dessa carência extrema que existia no campo de concentração, Primo Levi se pergunta se valeria a pena falar disto numa frase muito significativa: "bem sei que, contando isso, dificilmente seremos compreendidos, e talvez seja bom assim". ${ }^{13} 0$ resgate da memória nem sem-

\footnotetext{
10 TODOROV, Tzvetan. Memória do mal, tentação do bem, p.199.

11 RICOEUR, Paul. La mémoire, l'histoire, l'oubli, p.106.

12 LEVI, Primo. É isto um homem?, p.25.

13 LEVI, Primo. É isto um homem?, p.25.
} 
pre é agradável e às vezes, como é o caso, é traumático. Se fosse possível esquecer todos esses momentos por que passaram os sobreviventes dos campos, eles provavelmente o fariam. A nosso ver, não é primordialmente alguma preocupação com a função social da memória, ou a necessidade de relatar para as novas gerações esses acontecimentos, para que eles não se repitam, que move os sobreviventes. 0 problema maior é que é difícil esquecer. 0 relato assume então uma função de catarse. Não ser compreendido pode ser bom porque implica envolver muito o leitor com esta miséria humana, algo que quem sofre de múltiplas formas, no vivido, na memória e na narrativa, não deseja.

Os relatos de Primo Levi nos revelam o trauma por que passou, mas também um desejo muito grande de compreender, um desejo que não chega de modo algum a ser o de perdoar ou de aceitar o que ocorreu. Em se tratando de males tão extremos como os do século XX, cabe se perguntar quais os limites desta compreensão. No caso do sobrevivente, todo o esforço de rememorar e analisar o ocorrido, já por si traumático, pode levar também a algo próximo de se banalizar e justificar o mal. Mais grave ainda, quando estes limites são transpostos, pode-se chegar quase à identificação com os responsáveis pelo mal. Devemos entender que "não cabe às antigas vítimas procurar compreender seus assassinos, tanto quanto não cabe às mulheres estupradas debruçar-se sobre a psicologia de seus estupradores. Nesse caso, a compreensão implica uma identificação com o carrasco, ainda que parcial e provisória, e isso pode acarretar uma destruição de si mesmo". ${ }^{14}$

Em Os afogados e os sobreviventes, seu último livro publicado em vida, Primo Levi nos mostra de forma mais clara o que esperara e o que havia encontrado na convivência com este passado para ele, e para tantos outros, traumático:

Não queremos confusões, freudismos vulgares, morbosidade, indulgência. 0 opressor continua como tal, tanto quanto a vítima: não são intercambiáveis, o primeiro deve ser punido e execrado (mas, se possível, compreendido), a segunda deve ser lamentada e ajudada; mas ambos, em face da indecência do fato que foi irrevogavelmente cometido, têm necessidade de refúgio e de defesa, indo instintivamente em busca disso. Não todos, mas a maioria; e com frequência por toda a sua vida. ${ }^{15}$

Apesar das dificuldades, é possível e necessário representar a Shoah. Não podemos adotar uma posição ingênua e mesmo retrógrada de pensar sua história apenas como aquilo que aconteceu, os fatos nus e crus. A história da Sho-

14 TODOROV, Tzvetan. Memória do mal, tentação do bem, p.146.

15 LEVI, Primo. Os afogados e os sobreviventes: os delitos, os castigos, as penas, as impunidades. Tradução de Luiz Sérgio Henriques. 2 ed. São Paulo: Paz e Terra, 2004, p.21. 
ah necessariamente também será uma história contada. Mesmo que em seus testemunhos os sobreviventes não encontrem parâmetros de comparação nos quais situar o que viveram. De qualquer forma, em se tratando de um trauma, "a 'passagem' do 'literal' para o 'figurativo' é terapêutica". ${ }^{16}$

$\mathrm{Na}$ obra de Primo Levi percebemos uma tensão sempre presente entre a necessidade e a impossibilidade de falar sobre ou de representar a Shoah, que se revela na difícil relação entre a memória e o esquecimento. Enquanto alguns sobreviventes procuraram esquecer, optando pelo silêncio, outros sentiram a necessidade de falar sobre o ocorrido, talvez também para conseguirem esquecer e ir adiante ou, nos termos de Márcio Seligmann-Silva: "Por um lado tanto o testemunho deve ser visto como uma forma de esquecimento, uma 'fuga para frente', em direção à palavra e um mergulhar na linguagem, como também, por outro lado, busca-se igualmente através do testemunho, a libertação da cena traumática". ${ }^{17}$

No campo de concentração a pessoa se perdia, não sabia mais quem ela era ou o que ela foi. Os sobreviventes precisavam de quem os ouvisse. Depois do campo, o testemunho funciona como uma forma de autoconhecimento, uma possibilidade de voltar a ser o mesmo, deixar de ser um número e se reencontrar. Este autoconhecimento não é algo que precede ou que vem depois do ato de testemunhar. 0 que o sobrevivente era, não se recupera mais, é uma perda radical e irrecuperável, talvez a maior expropriação imposta por seus algozes. O sobrevivente sente que ele é o seu testemunho. 0 testemunho é uma forma de assinatura. ${ }^{18}$

Mas estes testemunhos de sobreviventes dos campos se defrontam com uma dificuldade básica de recepção, qual seja a de que

se trata de experiências limites, propriamente extraordinárias - que se defrontam com um caminho difícil em direção a capacidades de recepção limitadas, ordinárias, de ouvintes educados à uma compreensão partilhada. Esta compreensão foi edificada sobre as bases de um senso de semelhança humana no plano de situações, de sentimentos, de pensamentos, de ações. Mas a experiência a transmitir é de uma desumanidade sem medida comum com a do homem ordinário. (...) Para ser recebido, um testemunho deve ser apropriado, ou seja, desembaraçado na medida do possível de toda estranheza absoluta que cria o horror. Esta condição drástica não é satisfeita no caso dos testemunhos dos sobreviventes. ${ }^{19}$

\footnotetext{
16 SELIGMANN-SILVA, Márcio. A história como trauma. In: NESTROVSKI, Arthur e SELIGMANN-SILVA, Márcio. (org.) Catástrofe e representação, p.89.

17 SELIGMANN-SILVA, Márcio. A história como trauma, p.90.

18 FELMAN, Shoshama. Educação e crise, ou as vicissitudes do ensino, p.64.

19 RICOEUR, Paul. La mémoire, l'histoire, l'oubli, p.223.
} 
Narrar é difícil, encontrar quem esteja interessado em ouvir também não é fácil. Se mesmo quem narra às vezes não consegue acreditar que tudo aquilo por que passou possa ter sido verdade, maiores dificuldades ainda encontra quem ouve ou lê em receber o que está sendo narrado. Receber pela atenção e o interesse implica um modo de compartilhar o vivido, o que quem não viveu tais experiências, mesmo também tendo passado pelos horrores da guerra, não tem condições de fazer. É por isso que "qualquer pessoa que fale ou escreva sobre campos de concentração é tida como suspeita; e se o autor do relato voltou resolutamente ao mundo dos vivos, ele mesmo é vítima de dúvidas quanto à sua própria veracidade, como se pudesse haver confundido um pesadelo com a realidade". ${ }^{20}$

Primo Levi nos fala de dois sonhos que tinha com frequência no campo de concentração. Um era com comida, com uma boa refeição em casa, outro, era um sonho particularmente angustiante: ele estava em casa, de volta, e narrava a pessoas queridas tudo o que vivera no campo. De inicio as pessoas o escutam e ele fala da cama dura, do companheiro que dividia com ele a cama e que ele temia acordar porque era mais forte que ele, da fome, do soco que recebeu de um guarda que a seguir mandou que ele fosse se lavar porque o nariz sangrava, do controle dos piolhos. A seguir narra como ele se sentia neste sonho: “É uma felicidade interna, física, inefável, estar em minha casa, entre pessoas amigas, e ter tanta coisa para contar, mas bem me apercebo de que eles não me escutam. Parecem indiferentes; falam entre si de outras coisas, como se eu não estivesse. Minha irmã olha para mim, levanta, vai embora em silêncio". ${ }^{21}$

Peter Pál Pelbart desenvolve uma interpretação muito apropriada deste sonho de Primo Levi no que ele chama de uma alegoria do sobrevivente. Nesta alegoria, narrada na forma de um sonho do próprio autor, o sobrevivente seria um espectro que carrega o cadáver de um mártir, no caso, o seu próprio cadáver ainda quente, palpitante, para dar-lhe uma sepultura entre os amigos. Este espectro procura nos bolsos do morto algo que ele não sabe bem o que é, mas este algo, por outro lado, é fundamental para ele dar seu testemunho sobre o morto e assim voltar à vida deixando de ser um espectro de si mesmo. ${ }^{22}$

Ter tanto para contar e não ter quem ouça, nem mesmo entre as pessoas mais próximas. Qual o sentido de se transmitir uma experiência já por si absurda? Qual o sentido do prazer inicial em falar com as pessoas de suas experiências? Dividir o sofrimento? Mas quem ouve não têm como imaginar a

20 ARENDT, Hannah. Origens do totalitarismo, p.489.

21 LEVI, Primo. É isto um homem?, p.60.

22 PELBART, Peter Pál. Cinema e holocausto. In: NESTROVSKI, Arthur e SELIGMANN-SILVA, Márcio. (org.) Catástrofe e representação, p.172. 
dimensão deste sofrimento e parece querer se distanciar dele. A angústia do sonho pode estar relacionada com o temor de não voltar fisicamente para os seus e para sua terra, como também com o temor de não conseguir sobreviver psicologicamente, de se transformar em um estranho, em alguém que não dispõe de coisa alguma de positivo para compartilhar.

Jeanne Marie Gagnebin, se referindo à literatura de testemunho ou à “literatura dos campos" de Primo Levi e Robert Antelme ${ }^{23}$ e ao seu desafio de encontrar as palavras certas para dizer o indizível, nos fornece uma boa explicação a respeito da dificuldade em representar o cotidiano dos campos, mas também sobre a inconveniência do que se diz. Estes sobreviventes,

sentem uma ânsia desenfreada de comunicar, de falar, de contar, de escrever e, ao mesmo tempo, têm a nítida percepção da vaidade desse empreendimento narrativo, porque ele é incapaz de dizer o horror dos campos; ademais ele também se choca contra a incompreensão, a má-vontade e a rejeição dos seus interlocutores, mesmo dos mais próximos. À vergonha que acomete o sobrevivente, por não ter morrido com seus companheiros, se acrescenta a vergonha de ter que falar, de só poder falar de maneira profundamente inconveniente. ${ }^{24}$

Ainda segundo Jeanne Marie Gagnebin, esta vergonha e inconveniência podem ser claramente percebidas na descrição feita por Robert Antelme de seu estado quando saiu do campo. Ele fala de

sua gigantesca diarréia tífica, que ele trouxe de Dachau e que o prostra sem forças, sem resistências, sem limites, que o esvazia de si mesmo e o entrega, no limiar da morte e da podridão, aos cuidados dos outros, dos amigos que não conseguem nem reconhecê-lo nesse corpo exangue e nauseabundo, nem reconhecer a comunidade de sentidos, pelos quais juntos lutaram, nessa verborragia interminável. ${ }^{25}$

Além do mais, quando da volta do sobrevivente para casa, se junta ao trauma vivido no campo e suas lembranças difíceis de superar, uma certa decepção com o retorno à vida em liberdade: “De volta para casa, ele não pode deixar de desejar uma espécie de gratificação, após os sofrimentos de-

23 Robert Antelme (1917-1990), poeta e membro da resistência francesa durante a ocupação alemã, foi deportado para o campo de concentração de Buchenwald em 1 de junho de 1944, sendo a seguir encaminhado para o pequeno campo de Gandersheim, anexo a Buchenwald. Ele é autor de $A$ espécie humana, um dos testemunhos mais conhecidos sobre os campos de concentração. Depois da guerra ele foi encontrado no campo de Dachau, esgotado por meses de detenção em condições deploráveis e sofrendo de tifo.

24 GAGNEBIN, Jeanne Marie. Palavras para Hurbinek. In: NESTROVSKI, Arthur e SELIGMANN-SILVA, Márcio. (org.) Catástrofe e representação, p.107.

25 GAGNEBIN, Jeanne Marie. Palavras para Hurbinek, p.107. 
sumanos que sofreu; ora, ele não a encontra. A desolação reina também fora dos campos, cada um se sente pressionado a pensar suas próprias feridas e a esquecer as desgraças de ontem; os sobreviventes, estes fantasmas, simbolizam um passado que se quer afastar". ${ }^{26}$

Ao tratar do que considera como uma crise do testemunho, Paul Ricoeur lembra muito bem que enquanto o historiador, em sua crítica das fontes, deve estar sempre atento à confiabilidade de certos testemunhos, evitando a impostura, no caso dos testemunhos dos sobreviventes dos campos há uma inversão de prioridades, pois neste caso, se trata antes de lutar contra a incredibilidade e o desejo de esquecer daqueles a quem os sobreviventes se dirigem. ${ }^{27}$

Temos uma tendência a pensar que a vida que um autor dá a seus personagens é sempre uma parte de suas próprias experiências de vida, como se todo texto fosse um texto autobiográfico. Tal tentação se faz ainda mais presente em se tratando de um sobrevivente dos campos de concentração que se tornou conhecido como escritor pelo relato de seu trauma. Cometemos o equívoco de transformar aquilo que o próprio autor considera como um dever seu, o de depor, em uma espécie de sina do autor. Não deixamos que ele escape ao seu testemunho; deve estar sempre depondo de uma forma direta, em suas memórias, ou indireta, em seus textos ficcionais. Mas, assumindo o risco de uma interpretação apressada e analisando em conjunto a obra ficcional e a obra de testemunho de Primo Levi, a sensação que temos é que de fato o passado lhe era muito pesado. Tal peso se revela numa impressão de que na obra que tem a experiência do campo de concentração como temática imediata, o autor consegue se soltar mais como escritor do que na obra de ficção, o que nos parece uma constatação um tanto quanto óbvia de que o escritor tem grandes dificuldades de se libertar de seu passado traumático.

No conto Trabalho criativo, integrante da coletânea Vício de forma, de 1971, o narrador, o escritor Antonio Casella, num dia de falta de inspiração, recebe a visita de um personagem de suas novelas que havia escrito antes e que the diz que havia resolvido escrever alguns contos que tinham a ele, Antonio, como personagem e lhe pede para que leia e opine sobre tais contos. Lendo então os contos, ele percebe, com algum alívio, que os mesmos são fracos e que o empenho declarado por este seu personagem em transformá-lo em um personagem coerente com sua pessoa foi malogrado. Acaba por aconselhá-lo a desistir e se dedicar à ciência. No mesmo conto, autor e personagem, agora invertidos, se referem aos ambígenos, que seriam sujeitos que são ao mesmo tempo pessoa e personagem, e da ambigüidade de sua condição. Esta ambiguidade envolvendo pessoa e personagem só se resolve, e de uma forma muito

26 TODOROV, Tzvetan. Em face do extremo, p.291.

27 RICOEUR, Paul. La mémoire, l'histoire, l'oubli, p.223. 
peculiar no conto quando Antonio, muito tempo depois, resolve escrever sua autobiografia. Nesta autobiografia Antonio acumula "em seu outro eu todas as virtudes que não soubera construir dentro de sua vida real"; cria "um mundo mais verdadeiro que o real", em cujo centro estava ele numa "vida plena e múltipla, como nenhum homem vivera". ${ }^{28}$

A partir de uma curiosidade, ou de um desejo de entendimento, que já possuía no Lager, e que não se limitava aos chefes nazistas, e, depois de ter lido dezenas de livros sobre a psicologia de Hitler, Stálin, Himmler e Goebbels e não se sentir satisfeito com seu conteúdo, Primo Levi discorre sobre o que considera a insuficiência essencial da página documentária. Para ele, "ela não possui quase nunca o poder de restituir-nos o íntimo de um ser humano: com essa finalidade, mais que o historiador e o psicólogo, são idôneos o dramaturgo e o poeta". ${ }^{29}$

$\mathrm{Na}$ leitura e no confronto entre as obras de testemunho e de ficção de Primo Levi sentimos esta dificuldade em separar pessoa e personagem. Por um lado, nos textos de testemunho sobre sua vida no campo de concentração os personagens são bem definidos e bem construídos na narrativa, o que não nos parece ocorrer da mesma forma nos textos ficcionais. Não que estes textos não sejam bem escritos. Não se trata disso. Os personagens de ficção estranhamente nos parecem produtos de uma escrita mais tensa e mais difícil do que os personagens reais do campo. A nosso ver isto pode se explicar pela dificuldade de Primo Levi em separar-se de suas criaturas, ou de seus fantasmas. Quem sabe se ele também não desejaria escrever sua autobiografia, ou mais propriamente sua obra, inteiramente pautada pela vida que ele não conseguiu e nem poderia ter conseguido viver e, neste caso, esta separação um tanto quanto arbitrária que fazemos de sua obra perderia ainda mais o sentido.

Em sua Consideração intempestiva sobre a utilidade e os inconvenientes da História para a vida, Friedrich Nietzsche compara o animal com o homem e diz que uma das causas básicas da infelicidade humana é a sua dificuldade em esquecer ou sua dificuldade em viver o presente, ao passo que o animal, na medida em que não possui a capacidade de se lembrar de coisa alguma, só vive o presente. 0 ser do homem é um ininterrupto ter sido e o passado se transforma em algo que lhe pesa:

0 animal, de fato, vive de maneira a-histórica: ele está inteiramente absorvido pelo presente, tal como um número que se divide sem deixar resto; ele não sabe dissimular, não oculta nada e se mostra a cada segundo tal como é, por

28 LEVI, Primo. 71 contos. Tradução de Maurício Santana Dias. São Paulo: Companhia das Letras, 2005, p.257.

29 LEVI, Primo. O último natal de guerra. Tradução de Maria do Rosário Costa Aguiar Toschi. São Paulo: Berlendis e Vertecchia, 2002, p.56. 
isso é necessariamente sincero. 0 homem, ao contrário, se defende contra a carga sempre mais esmagadora do passado, que o lança por terra ou o faz se curvar, que entrava sua marcha como um tenebroso e invisível fardo. ${ }^{30}$

O homem não pode "aprender o esquecimento" e assim fica sempre prisioneiro do passado. Admira-se de constatar esta capacidade de não se lembrar do passado nos animais e inveja a criança que ele deixou de ser, "que não tem ainda um passado para negar e que brinca, na sua feliz cegueira, entre as balizas do passado e do futuro". ${ }^{31}$

Em 1986, são apresentadas a Primo Levi duas fotografias de um companheiro de campo, que havia morrido na marcha de transferência de prisioneiros de Auschwitz para Buchenwald no final da guerra. Os membros da família deste prisioneiro procuravam saber se ele o conhecera no campo e, entre outras coisas, se seu parente não havia sofrido muito com a fome. Reconhece facilmente naquelas fotografias o austríaco Gerhard Goudbaum e procura confortar seus familiares dizendo que ele não deve ter passado muita fome já que o havia reconhecido em fotografias de 1939. Mas para si mesmo diz outras coisas sobre sua memória: de que às vezes, e não apenas no que diz respeito à Auschwitz, se sentia como um irmão de Irineo Funes, el memorioso, de Jorge Luís Borges, descrito pelo grande escritor argentino como uma pessoa que lembrava cada folha de cada árvore que tivesse visto, e que tinha "mais lembranças sozinho do que quanto poderiam ter todos os homens que viveram desde que o mundo existe". Chama então sua memória daquele período de memória patológica. ${ }^{32}$

A dificuldade maior para os sobreviventes é o esquecimento ou a frequência exagerada da lembrança. A propósito, vale notar que:

A memória não se opõe absolutamente ao esquecimento. Os dois termos que formam contraste são a supressão (o esquecimento) e a conservação; a memória é, sempre e necessariamente, uma interação dos dois. A reconstituição integral do passado é coisa impossível. Se existisse seria pavorosa, como o mostrou Borges em sua história de Funes, el memorioso. A memória é forçosamente uma seleção: certos detalhes do acontecimento serão conservados, outros, afastados, logo de início ou aos poucos, e portanto esquecidos. ${ }^{33}$

30 NIETZSCHE, Friedrich. Consideração intempestiva sobre a utilidade e os inconvenientes da História para a vida. In: Escritos sobre a história. Tradução de Noéli C. de Melo Sobrinho. Rio de Janeiro/São Paulo: PUC/Loyola, 2005, p.71.

31 NIETZSCHE, Friedrich. Consideração intempestiva sobre a utilidade e os inconvenientes da História para a vida, p.71.

32 LEVI, Primo. O último natal de guerra, p.121.

33 TODOROV, Tzvetan. Memória do mal, tentação do bem, p.149. 
Para Nietzsche o passado é sempre traumático e daí a necessidade da faculdade de esquecer já que "toda ação exige esquecimento, assim como toda a vida orgânica exige não somente a luz, mas também a escuridão". ${ }^{34}$ Deve-se ser capaz de separar o que deve ser esquecido do que deve ser lembrado. Há pessoas que possuem mais, e outras menos, a força para "transformar e assimilar as coisas passadas ou estranhas, curar as suas feridas, reparar as suas perdas, reconstituir por si próprio as formas destruídas”. Esta força é algo primordial para o próprio senso histórico de um indivíduo ou de uma cultura, é também fundamental para que o passado "não se torne o coveiro do presente". ${ }^{35}$

$\mathrm{Na}$ obra de Primo Levi encontramos pistas e sinais de suas visões de mundo, de suas sensibilidades e de sua personalidade, além, é claro, de suas experiências pessoais de vida. Encontramos também sinais que parecem querer nos despistar ou nos fazer desistir desta espécie de decodificação. Justamente num conto com este título - Decodificação -, do livro Lilith, de 1978, o narrador, em suas reflexões sobre os dilemas de um adolescente que ele vira pichando muros com dísticos fascistas e suásticas, nos diz sobre o quanto pode ser infrutífera este tipo de busca:

Pensava também na essencial ambiguidade das mensagens que cada um de nós vai deixando para trás, do nascimento até a morte, e na nossa profunda incapacidade de reconstruir uma pessoa por meio delas, o homem que vive a partir do homem que escreve: quem quer que escreva, mesmo que apenas nos muros, o faz em um código que é só seu, que os outros desconhecem - e quem fala também. Transmitir com clareza, exprimir, exprimir-se e tornar-se explícito é coisa para poucos: alguns poderiam e não querem, outros gostariam, mas não podem, e a maior parte não quer nem sabe. ${ }^{36}$

Se insistimos nesta análise da obra não é de forma inadvertida, ou apesar das advertências do próprio autor, e sim porque acreditamos que uma obra sempre nos diz algo de interessante sobre seu autor e sobre sua época mesmo que de um modo cifrado e indireto, ou seja, estamos conscientes do risco que corremos. Vale lembrar os argumentos clássicos de Marc Bloch em favor dos testemunhos indiretos em relação aos diretos para a história. Se tratarmos as obras de ficção, e mesmo de ficção científica, como é às vezes o caso de Primo Levi, com o devido cuidado e as devidas mediações, elas podem sim serem

34 NIETZSCHE, Friedrich. Consideração intempestiva sobre a utilidade e os inconvenientes da História para a vida, p.72.

35 NIETZSCHE, Friedrich. Consideração intempestiva sobre a utilidade e os inconvenientes da História para a vida, p.73.

36 LEVI, Primo. 71 contos, p.509. 
tratadas como uma fonte, ou mais precisamente como testemunhos indiretos para a história.

Em Os Mnemagogos, primeiro conto integrante do livro Histórias naturais, de 1966, o velho médico Montesanto, um sobrevivente das trincheiras da Primeira Guerra, se recolhe em um pequeno povoado depois das desilusões de uma carreira universitária fracassada. Na sua vida de solitário, o que resta é apenas "a prevalência definitiva do passado sobre o presente e o naufrágio último de todas as paixões, salvo a fé na dignidade do pensamento e a supremacia das coisas do espírito". ${ }^{37}$ Montesanto, a quem causa horror pensar que uma só de suas lembranças se perca, explica ao jovem médico Morandi como criou, a partir de sua experiência de farmacologista, um novo método de conservar sensações que certos odores têm o poder de evocar. Os seus mnemagogos, ${ }^{38}$ ou suscitadores de memória, são pequenas garrafas com certos líquidos que ao serem cheirados conduzem pelo olfato a experiências vividas. Do primeiro mnemagogo com o qual Morandi tem contato ele diz que têm um cheiro de caserna, mas para Montesanto, o cheiro é de sua sala na sua escola primária e tudo o que ela representava para ele. Acrescenta ainda que é mais do que isto: é o cheiro da infância dele Montesanto.

Para Morandi o cheiro do conteúdo de outra garrafinha seria de maçãs guardadas para amadurecer em um pequeno quarto na casa de seu avô. Para Montesanto, o cheiro seria o do hálito do diabético em fase terminal, ou mais precisamente, o cheiro da morte de seu próprio pai, que morreu de diabetes e a quem ele velou por noites inumeráveis no leito. Mas não foram vigílias estéreis já que seu pai representava muito para ele e nestas vigílias muitas de suas crenças foram abaladas e muito de seu mundo mudou. Para ele, portanto, "não se tratava apenas de maçãs ou diabetes, mas do sofrimento solene e purificador, único da vida, de uma crise religiosa". ${ }^{39}$

37 LEVI, Primo. 71 contos, p.27.

38 A mnemotecnia é uma técnica da memória que teria sido criada na Grécia antiga sendo normalmente atribuída a Simônides de Ceos (por volta de 556-468 a.C.). Cícero, em De oratore (II, LXXXVI) contou sobre a forma de uma narrativa religiosa, a invenção da mnemotecnia por Simônides. Um nobre de Tessália, Escopas, teria contratado Simônides para declamar os dotes atléticos de um vencedor no pugilismo durante um banquete por ele oferecido. Mas ele ornamentou seu poema com muitas referências a Castor e Pólux. Escopas diz então a Simônides que lhe pagará apenas a metade do preço combinado e que ele deveria cobrar a outra metade aos próprios Dióscuros [Na mitologia grega, os gêmeos Castor e Pólux são chamados Dióscuros, que significa jovens de Zeus]. Pouco depois alguém vem até Simônides lhe dizendo que dois jovens procuravam por ele. Ele sai e não vê ninguém. Mas enquanto estava fora, o teto da casa desaba sobre Escopas e seus convidados. Os cadáveres esmagados ficam irreconhecíveis. Simônides, lembrando-se da ordem em que estavam sentados, os identificará, permitindo que eles fossem entregues às suas respectivas famílias. A técnica, em sua origem, portanto, está associada a lembranças de imagens necessárias à memória apoiadas sobre uma organização e uma ordem, essenciais a uma boa memória. Cf. LE GOFF, Jacques. Histoire et mémoire. Paris: Gallimard, 1988, p.127.

39 LEVI, Primo. 71 contos, p.30. 
Quando Morandi pergunta sobre uma outra garrafinha ou mnemagogo, a resposta que recebe é a de que aquele não era um lugar nem um tempo; era uma pessoa. Antes Montesanto já havia dito que os mnemagogos, e seu poder evocativo de sensações do passado distante ou, podemos dizer, da memória, eram estritamente pessoais e acrescenta que, "aliás, pode-se dizer que são a minha pessoa, já que em parte eu consisto neles". ${ }^{40}$

Um outro suscitador de memória tinha um cheiro ardente, enxuto e quente para Morandi e o levava a se lembrar de quando se chocam duas pedras de ignição. Para Montesanto o cheiro da substância ali contida era o mesmo do que se sentia no alto da montanha, quando a rocha se escalda ao sol, especialmente quando há um desmoronamento de pedras. Diz a Morandi que antigamente ele ia muito à montanha, quase sempre sozinho e quando chegava ao topo, deitava-se sob o sol. No ar parado e no silêncio daqueles momentos the parecia que ele havia alcançado um objetivo. Ali sentia um cheiro suave, raro de ser sentido em outros lugares. Este mnemagogo era para ele a sua maior descoberta científica e a sensação por ele evocada era a da paz conquistada. Em suas dificuldades em superar as lembranças traumáticas de seu passado, talvez fosse exatamente isto que Primo Levi procurava, reencontrar-se em suas memórias e conquistar paz em sua vida.

Em 11 de fevereiro de 1944 Primo Levi foi enviado para Auschwitz como parte de um grupo de 650 prisioneiros. Ali permanecerá até janeiro de 1945, quando da evacuação do campo ante a eminente chegada do Exército Vermelho. Em 27 de janeiro de 1945 o campo é liberado pelos russos. Daqueles 650 prisioneiros italianos, somente 20 conseguiram sobreviver e retornar à sua terra natal ao final da guerra. Seu retorno para a Itália ocorrerá somente em outubro de 1945, depois de permanecer por algum tempo em um campo soviético para recuperação de antigos prisioneiros dos campos de concentração e depois de uma longa viagem em companhia de prisioneiros italianos de guerra capturados no front russo.

Voltando para casa em Turin, procura retomar sua vida e o faz se dedicando de imediato à escrita de suas memórias sobre este um ano em Auschwitz ao mesmo tempo em que retoma seu ofício de químico. Dedica-se depois também a uma obra ficcional na qual se reafirma seu talento de escritor e que se revela importante para melhor compreendermos o universo concentracionário que descreve em seus textos de testemunho. Procuramos tomar as duas faces de sua produção em conjunto para tratar das questões a que nos propusemos. Esta aproximação entre literatura e história se revelou muito profícua.

Para um sobrevivente dos campos de concentração, narrar sua vida naquelas condições não era tarefa fácil. Se pudesse, talvez preferisse simplesmente

40 LEVI, Primo. 71 contos, p.29. 
esquecer. 0 esquecimento, no caso, seria tanto para os outros como para si mesmo. Mas não era fácil esquecer. Tratava-se do caso clássico do passado que se recusa a passar. Para conviver com este passado era necessário falar sobre ele, ou seja, testemunhar. Mas era difícil falar e havia grandes dificuldades na recepção destes testemunhos. Aquele que falava sobre o que viveu no campo sentia isso. Todos, tendo passado ou não pelos campos, queriam esquecer a guerra. Todos necessitavam de uma vida nova. Quem sobreviveu aos campos de concentração temia se transformar em um estranho, em alguém que não dispõe de coisa alguma de positivo para compartilhar.

Escrevendo sobre sua vida e sobre si mesmo, o sobrevivente de alguma forma se reencontra. Não se trata de uma volta ao que era antes. Não existe mais a pessoa de antes do campo. Já o antigo prisioneiro teima em sobreviver pela nossa ideia equivocada do dever de memória. Sentimos que Primo Levi testemunha pela necessidade de se libertar de uma parte de seu passado para conseguir viver o presente e ter um futuro possível. Podemos nos perguntar sobre qual teria sido seu ganho resgatando suas memórias. Se este resgate o levou, como a Montesanto, do conto Os Mnemagogos, pelo menos em alguns momentos, a reencontrar-se em suas memórias e conquistar paz em sua vida. Até que ponto conseguiu isto, só ele o poderia dizer. Mas nós ganhamos muito. Abordando suas obras de ficção em conjunto com as obras de testemunho, como o fizemos neste artigo, podemos compreender melhor a complexa relação entre a memória, o esquecimento e a construção da narrativa em história. Esta obra também nos revela aspectos fundamentais da história do século XX em seus momentos cruciais e do que permanece de humano nas pessoas nesses momentos. Acreditamos que Primo Levi fez bem, e nos fez bem, em vencer seu dilema sobre falar ou não do ocorrido em Auschwitz. Ganhou ele por ter condições um pouco melhores de conviver com seu trauma e ganhamos nós leitores pelo legado de sua obra. 